\title{
Belarusianisation and its Myths
}

\author{
BY \\ SIARHEI BOHDAN
}

\author{
Aliena Markava \\ Šliach da savieckaj nacyi: palityka bielarusizacyi (1924-1929). \\ Minsk: Halijafy, 2016. 324 p. \\ ISBN: 9789857140367
}

This book presents a revised and expanded Belarusian translation of a doctoral thesis defended by Aliena Markava at Charles University in Prague. It has been positively reviewed by the well-known Czech historian, Miroslav Hroch, which raises readers' expectations.

Indeed, the study uses a significant number of archival documents and various primary sources. The book will undoubtedly contribute to better understanding of Belarusianisation and cultural policies in Soviet Belarus.

The publication avoids radical conclusions, yet presents a rich body of evidence that will allow readers to draw their own. Just one example, Markava herself on many occasions cites significant measures undertaken by the Bolshevik party and the state aimed at the promotion of Belarusian culture, and which long pre- or post-date the official period of Belarusianisation policies. Yet Markava sticks to the traditional time frame of Belarusianisation, corresponding precisely with the official decisions of Communist party bodies. It looks like the author has deliberately left the reader to conclude themself whether such measures break the stereotypes of existing scholarship.

The book debunks a series of important myths about modern Belarusian history. First, it debunks myths about the attainments of Belarusianisation policies. Markava has considered numerous cases demonstrating that these policies in the 1920s were officially implemented in nearly every sphere: from education to internal affairs, from army to land regulation agencies. Chapters Five and Seven are full of relevant statistics, quotations from official reports, internally-circulated documents of the supervising bodies, and other such evidence. One thing clearly emerges from Markava's archival sources: the official published reports of the time draw a picture far removed from the reality of hard struggle to implement at least 
some Belarusianisation measures. This is an important finding since researchers in recent decades have most frequently used more easily accessible official documents published for wider audiences.

The author admits that the effective results achieved by the end of the $1920 \mathrm{~s}$ were humble. Moreover, according to Markava, these political measures stopped after the well-known Zatonski report in 1929. That begs the question of how it came to be in 1939 that almost all schools in Belarus (93.4\%) had Belarusian as the language of instruction; an observation the book itself makes (p. 265)? In other words, our ideas about Soviet government policies toward Belarusian culture need to be revised, since the introduction of the language came after the official end of Belarusianisation, and other related policies apparently continued.

Meanwhile, Markava challenges certain myths about the opposition to the Belarusian nationalist intelligentsia. She describes the activities of Vilíhieĺm Knoryn, a high-ranking Bolshevik official frequently cited by Belarusian nationalist activists as a symbol of Bolshevik's Belarusophobia.Yet she quotes specific cases of Knoryn expressing support for the Belarusian culture, language and empowerment of Belarusian ethnic population (e.g., pp. 88, 204, 220).

Despite the virtues of the publication, the book would gain significantly from closer integration with the existing scholarship. Although Chapter One mentions some Western scholarly publications, among them Terry Martin, Anthony Smith and Francine Hirsch, there are no references to them elsewhere in the text. The actual theoretical framework of the book becomes clear only at the very end, and it is effectively limited to applying Miroslav Hroch's theory of three phases of national movement to the Belarusian case.

This minimal conceptualisation of the study jars with the author's normative statements in the foreword and afterword, and which clearly contradict the objectivity premise universally adopted in contemporary scholarship. According to the author:

The current situation in Belarus may seem even more incomprehensible for the foreign observer, especially when he learns that the majority of Belarusians do not speak the Belarusian language, do not use the traditional symbols of the state chosen after the proclamation of the Republic of Belarus's independence in 1991, and do not even always choose for themselves the Belarusian national identity which is based on the national language and national heritage (p. 9).

This and other normative statements of the author (e.g., in afterword, p. 289) stand in stark contrast to the thematic core of the publication which presents a mostly neutral text, appropriate for scholarly studies. 
The classification and characterisation of existing studies would have benefited from a more neutral and critical approach. The author announces (p. 14) that the studies done on Belarusianisation by listed Polish authors in the 1920s aimed at objectivity - yet this statement is far from obvious and no argumentation is provided. In a similar vein, she praises the publications of the Munich Institute for the Study of the USSR for 'their authors' aspiration to objectively deal with the issues they studied' (p. 19). However, in Western academia the Institute and its publications are considered as highly controversial, at least, because of the institution's close links to the US special services, and for its other publications which hardly fit the requirements appropriate for scholarly studies ${ }^{1}$.

The Soviet Union conducted Belarusianisation policy as part of an all-Union policy, so the study would have gained from placing the issue into a broader context, drawing comparisons, and using the findings of the respective studies of other Soviet republics.

The explanation for these policies, their launch and dynamics, also lies outside the narrow Belarusian context. For instance, the Bolsheviks hardly needed Belarusian nationalists to solve acute issues of what were then current politics. Markava avoids saying this clearly although she cites multiple pieces of evidence of the weak support for Belarusian identity. This evidence contradicts the widely maintained version, which claims that the Communist state in the 1920s could have exploited some of the ideas and proponents of Belarusian nationalism to consolidate its power in the eastern Belarusian regions and prepare the ground for conquering western Belarusian regions then administered by Poland.

Given the picture Markava draws in the book of an opaque Belarusian identity held by few intellectuals and activists, the Soviet state could have made some real political use of Belarusian nationalism only in a very distant future, for example, after and if the Communist government had invested huge resources into the formation, dissemination and consolidation of a distinct Belarusian identity. Therefore the government of such an impoverished and war-destroyed country, as the Soviet Union was back then, could hardly decide to launch Belarusianisation following some pragmatic political logic of the exploitation of a Nationalist movement.

Markava's book leaves these paradoxes of the nationalities policy of the Bolshevik government effectively untouched. However, the Bolshevik authorities' support for new national identities, even in locations where they were only held by few intellectuals and activists, has already been studied in some other of the

\footnotetext{
' See, for instance, Suny, Ronald Grigor, 1995. 'Rethinking Soviet Studies: Bringing the Non-Russians Back In,' in Daniel Orlovsky, ed., Beyond Soviet Studies. Washington, D.C.: Woodrow Wilson Center Press, pp. 108-109.
} 
Soviet republics whose populations had no clear national identity at the time. Some of these studies provide interesting insights and approaches to understand the Belarusian situation, as well.

David L. Hoffmann suggests we look for the explanation of the Communist government's approach in general concepts of Bolshevik doctrine ${ }^{2}$. According to him, the Soviet Communist party viewed the establishment of separate nations each with the set of cultural, political and economic attributes that belong to 'genuine nations' - as an indispensable premise for achieving Communism.

Moreover, the model of relations between the Bolshevik authorities and local Belarusian intelligentsia resembles the processes that occurred in other regions of the Soviet Union. Adeeb Khalid describes how Bolsheviks and local religious and nationalist intellectuals interacted and collaborated in Central Asia ${ }^{3}$ and how the Bolsheviks there used Jaddids, non-Marxist nationalist and Islamist intellectuals, to shape a new culture and fight against the domination of conservative social groups. In exchange, Communist authorities provided Jaddids with opportunities to implement some of their ideas which otherwise could never have been realised. That model worked for some time and ended at approximately the same time as in Belarus.

Markava also refrains from analysing the developments in terms of the political struggle both inside and outside the Communist party beyond the simple binary scheme of 'Bolsheviks versus Belarusian intelligentsia.' The book tacitly agrees with the widespread view that the Belarusian intelligentsia simply wished to conduct cultural activities under Bolshevik rule and harboured no political ambitions of its own. That is, however, a moot point.

The author has generally kept analysis of political fights or looking for clash of interest in studying cultural developments in the BSSR of the 1920s to the minimum. Thus, she even insists that no socioeconomic contradictions existed between ethnic Belarusians and other ethnic groups, so 'the national agitation could not exploit acute and clearly expressed nationally relevant conflicts of interest between Belarusians and other peoples [actually, ethnic groups of the population of Belarus are meant here]' (p. 281). Yet these contradictions are evident even from the very brief comments on population and class structure in Belarusian society of the time provided in the book - where nearly all ethnic Belarusians were peasants as well as from the fact there was only a marginal presence of Belarusians in urban settlements and their underrepresentation in many trades.

2 Hoffmann, David L. 2003. Stalinist Values: The Cultural Norms of Soviet Modernity, 1917-1941. Ithaca, NY: Cornell University Press.

3 Khalid, Adeeb, 2015. Making Uzbekistan: Nation, Empire, and Revolution in the Early USSR. London: Cornell University Press. 
Against this backdrop, the activities pursued by the Belarusian nationalist intelligentsia, as well as the version of national identity that Belarusian intellectuals cooperating with the Bolsheviks via state institutions had developed and introduced, took on a sometimes controversial character. Indeed, Markava's decision in Chapter Six to analyse the model of national identity proposed by those Belarusian intellectuals who collaborated with Soviet authorities in constructing the institutions of the Soviet Belarusian republic provides the book with an extremely interesting analysis which, however, needs further examination.

First, the model which many Belarusian nationalist intellectuals of various political colours could promote (thanks to the Bolsheviks' outsourcing that task for a while) reveals the strong aspiration to build an ethnic nation, one which has no problem with even some racial undertones (see, for instance, pp. 182-183). The reader can only wonder how far Belarusian nationalists, working in the service of the Bolshevik state, really wanted Jews or any other non-Belarusian groups collaborating with their efforts bearing in mind the prominence they gave to Belarusian ethnic purity or Aryan roots (e.g., p. 183). Markava quotes examples of such discourse from the now classical texts of Belarusian nationalist intellectuals like Arkadź Smolič.

Second, the model of national identity promoted in the 1920s undoubtedly resulted in very real conflicts with other ethnic groups living in Belarus at the time and which constituted a majority in towns and cities. After all, Belarusianisation policies as an affirmative action programme included not only the introduction of the Belarusian language or the printing of more Belarusian books, but also the Bolsheviks' firm line on increasing the share of ethnic Belarusians in the Party, state and party offices, educational establishments, some trades and professions. This meant providing them with access to resources and power at the cost of nonBelarusian ethnic groups which previously enjoyed that access.

Markava describes and analyses cases of the latter groups' refusal to support Belarusianisation measures. In some cases, the sabotage of Belarusianisation resulted in active and successful resistance to it (e.g. the case of Babrujsk railway employees (pp. 113-115)). Of course, it was not only non-Belarusian ethnic groups that sabotaged Belarusianisation, many Belarusians had problems with the policies too and resisted them, as Markava notes. Unfortunately, she tends to ascribe their behaviour to their lack of national consciousness. Her text gives the impression that the Belarusian national identity was something objectively existing and not just a set of different socially constructed concepts. That is, the book tacitly ignores the possibility that these 'unconscious' Belarusians merely held other ideas about national identity than those generated with the involvement of Belarusian nationalist intellectuals and promoted by Bolshevik authorities. 
The book, which excellently analyses the Belarusianisation policy measures within their official timeframe, somehow abruptly drops its thorough investigation as it reaches the moment of the Bolsheviks' renunciation of these policies. In a stark contract to the rest of the book, Chapter Eight, dedicated to the end of these policies, contains almost no references to archival materials and relies heavily on documents published in books or periodicals, sometimes of uncertain veracity. In some instances it has adverse consequences. For example, the author quotes a decision on language reform from a book by Lieanid Lyč (p. 263) which wrongly assumes that 'removal of the artificial barrier between Belarusian and Russian languages' was one of the official aims of the 1933 Belarusian orthography reform.

A more detailed consideration of developments after the official end of Belarusianisation policies, and a more consistent attempt to discover whether the Soviet state effectively stopped it or it ended for some other reason, would have benefitted the book. That omission is remarkable given that the author herself concedes that, after the 1929 Zatonski report, prominent Bolshevik officials and state agencies pledged to continue the Belarusianisation. Moreover, some Belarusianisation measures actually continued. The study could have brought about revolution in our understanding of Belarusianisation policies if it simply had considered actual developments and not just referred to an official speech by a party official and related decisions.

The book has done a valuable service to Belarusian society and Belarusian studies. It helps Belarusians understand their origin as a modern nation and a polity. In particular, Belarusian readers of the book will better understand why Belarusian politics still involves so many issues related to national identity, in particular the language issue.

In particular, the book will help them to get rid of the fantastic myth of a once existing "Belarusian Belarus", an idyllic, effectively ethnic nation destroyed by either Russian or Soviet invasion and suppression - a myth which started to circulate with the latest rise of the Belarusian Nationalist movement in the late 1980s.

It also warns against putting too much emphasis on state measures for the revival of national culture - such wishes the reviewer has many times heard from prominent contemporary Belarusian intellectuals. For Belarusian studies, the publication provides an evidence-based study of a key period in Belarusian history. Markava's explicit and implicit findings will also cause re-evaluation and reconsideration of other periods and developments in modern Belarusian history, as well, including the recent three decades during which the political forces that regard themselves as the heirs to the Belarusian Nationalist intellectuals of the 1920s have failed to obtain power in independent Belarus. 